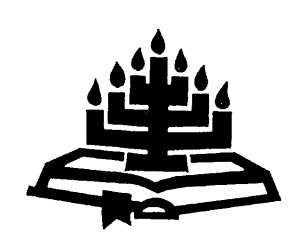

\title{
Stamselnavorsing en terapie: 'n voorlopige teologies-etiese beoordeling
}

\author{
A.L. Rheeder \\ Skool vir Kerkwetenskappe \\ Potchefstroomkampus \\ Noordwes-Universiteit \\ POTCHEFSTROOM \\ E-pos: corriaan1@942.co.za
}

The optimism that we can improve life and relieve suffering is our humanity. (Christopher Thomas Scott, 2006 Standford University lecturer.)

\begin{abstract}
Stem cell research and therapy: a preliminary theologicalethical evaluation

Researchers have already created wonderful and fascinating therapeutic results with stem cells. Human beings and animals have been cured of a variety of ailments through the use of stem cells. For a large number of human beings the possibility of a cure through stem cell research and accompanying therapy has tremendous possibilities. The aim of this article is a theological evaluation of this medico-technological phenomenon in general. What does the Bible teach us about the cure of sick people? Can Christ's teaching and life aid us in this regard? In answering this question the meaning of the escatological ethics will be examined as well. Various arguments for and against this technology are examined. The most important ethical question concerning research and therapy in particular is the unavoidable destruction of human embryos. Human embryos are donated and sometimes created with the aim of harvesting cells. Numerous arguments for and against the destruction of embryos are treated. The ethical argument that human embryos may be destroyed for the purpose of possible cure is evaluated philosophically in the light of the Scripture.
\end{abstract}




\title{
Opsomming
}

\section{Stamselnavorsing en terapie: 'n voorlopige teologies-etiese beoordeling}

\begin{abstract}
Stamselnavorsers het al wonderlike en asemrowende terapeutiese suksesse met stamselle bewerk. Mens en dier is deur middel van stamselle van 'n verskeidenheid siektes verlos. Vir baie mense hou die moontlikheid van genesing deur stamselnavorsing en meegaande terapie ontsaglike hoop in. Die doel van hierdie artikel is om hierdie medies-tegnologiese verskynsel in die algemeen teologies-eties te beoordeel. Wat leer die Bybel ons oor die genesing van siek mense? Kan Christus se leer en lewe ons in hierdie verband help? In die beantwoording van die vraag sal ook na die betekenis van die eskatologiese etiek gekyk word. Verskeie argumente vir en teen hierdie tegnologie word behandel. Die groot etiese vraag rondom stamselnavorsing en terapie in die besonder is die noodwendige vernietiging van menslike embrio's. Menslike embrio's word geskenk en soms geskep met die doel om stamselle te oes. Verskeie argumente vir en teen die vernietiging van die embrio word behandel. Die etiese oordeel dat menslike embrio's met die oog op moontlike genesing vernietig mag word, word filosofies en in die lig van die Skrif beoordeel.
\end{abstract}

\section{Inleidend}

In 'n vorige artikel (Stamselnavorsing: 'n oorsig oor die uitvoerbaarheid daarvan met meegaande etiese implikasies; Rheeder, 2008:469-497) is aan die aktualiteit, uitvoerbaarheid en etiese probleme van stamselnavorsing en terapie aandag gegee. Daardie inligting word by hierdie artikel veronderstel en word nie herhaal nie. Wat baie duidelik uit die navorsing na vore gekom het, was dat stamselle ongelooflike genesingspotensiaal besit en dat die gebruik van stamselle tot die genesing van verskeie ernstige siektes by mense en diere gelei het. Stamselle is spesiale selle wat die vermoë het om tot enige sel in die liggaam te ontwikkel en defektiewe selle te herstel of te vervang. Navorsers het stamselle uit menslike (en dierlike) embrio's (embrionale stamselle), fetus, naelstring en die volwasse liggaam (bekend as volwasse stamselle) geïsoleer en tot stamsellyne voorberei vir terapie. Verbasende resultate is alreeds aangetoon. In sommige gevalle het navorsers ten volle genesing bewerk of ten minste groot verbetering tot stand gebring in diere (in enkele gevalle by mense) met suikersiekte, Parkinson en Alzheimer se siektes en outo-immuunsiektes. Die gebreekte rugmurg van rotte is ook al deur hierdie tegnologie herstel. Probleme wat geïdentifiseer is, is die noodwendige vernietiging van die menslike embrio, die 
oorweging van terapeutiese kloning, plasing van menslike embrionale stamselle in embrio's van primate soos ape en 'n reeks tegniese en veiligheidsprobleme in die ontwikkeling van stamseltegnologie. 'n Mens kom dus tot die gevolgtrekking dat, indien die tegniese en etiese probleme van stamselnavorsing en -tegnologie oorkom kan word, hierdie mediese tegnologie wonderlike genesing in 'n verskeidenheid siektes by die mens in die nabye toekoms tot gevolg sal kan hê.

Die etiese probleem wat in hierdie artikel bespreek word, handel oor die vraag of menslike embrio's vir navorsingsdoeleindes en stamselterapie gebruik mag word (Van Niekerk, 2005:201). Menslike embrionale stamselle word eksklusief uit die binneste selmassa verkry (Panno, 2006:5). Die groot etiese probleem rondom die gebruik van menslike embrio's bestaan daarin dat die proses van die verkryging van selle uit die binneste selmassa doelbewus lei tot die vernietiging van die embrio (Monitoring stem cell research, 2004:8, 19; Scott, 2006:50-52, 126; Tada \& Cameron, 2006:142). "There is no way to remove cells from the ICM of a blasocyst without killing the embryo", skryf Panno (2006:23). Tesame met die bespreking van bogenoemde etiese probleem sal stamselnavorsing in die algemeen teologieseties as mediese tegnologie beoordeel word. Soos by die vorige artikel (Rheeder, 2008) moet die teologies-etiese oordeel ook as voorlopig beskou word.

Die Amerikaanse President's Council on Bioethics het na 'n deeglike en intensiewe studie van stamselnavorsing tot die gevolgtrekking gekom dat biologie en filosofie alleen nie voldoende is om morele vrae rondom stamselnavorsing te beantwoord nie (Monitoring stem cell research, 2004:14-15). Hiermee saam is moderne wetenskaplikes ook van oordeel dat die Bybel nie ingespan kan word om morele vrae oor hedendaagse biomediese tegnologieë soos stamselnavorsing te beantwoord nie. Die Bybel veronderstel 'n verstaan van die werklikheid en wêreldbeeld wat radikaal verskil van hoe ons die werklikheid van die hedendaagse molekulêre biologie verstaan. "Oor hierdie moderne sake moet mense - insluitende Christene van hulle gesonde verstand en hul normale morele oordeelsvermoë gebruik maak, met behulp van soliede eties-filosofiese argumente", skryf Van Niekerk (2005:203-204). Hy waarsku teen ongeloofwaardige aangryping van Bybeltekste, wat nog geen wete gehad het van die kwessies waaroor dit vandag gaan nie. Myns insiens moet 'n etiese beoordeling van stamselnavorsing gedoen word met 'n kombinasie van biologiese, filosofiese en Skriftuurlike gegewens (Fil. 1:10; Heb. 5:14; NGB, art. 2). 
Wanneer gestel is dat geen direkte antwoord of direkte teksbewyse met betrekking tot moderne etiese vraagstukke bestaan nie, kan egter nog steeds met groot vertroue na die Bybel gekyk word en moet dit ernstig opgeneem word (Van Niekerk, 2005:207) vir leiding en antwoorde (Higginson, 1995:97; Tada \& Cameron, 2006:30). Hier word van 'n ander soort Skrifberoep gebruik gemaak as blote teksverwysings. Indien spesifieke teksverwysing dus ontbreek, moet rekening gehou word met die totale struktuur van die Bybelse boodskap (Van Wyk, 1991:23). Die hele Bybel kan gebruik word om die denke in 'n bepaalde rigting te oriënteer met betrekking tot stamselnavorsing (vgl. Mortensen, 1995:viii). Dit impliseer dat met bepaalde temas in die Bybel gewerk word (vgl. Higginson, 1995:97). Ouweneel (1978:21) praat van "algemene beginsels" wat in die Woord gevind word. In hierdie verband kan die volgende onderskeiding van hulp wees (vgl. Van Wyk, 1999:89): “' 'n Saak is Skriftuurlik (beklemtoning - JHvW) wanneer dit direk in die Skrif bespreek en besleg word, maar dit is Skrifmatig (beklemtoning $\mathrm{JHvW}$ ) wanneer dit nie direk (...) of in die geheel (...) in die Skrif ter sprake kom [nie], maar tog korreleer met die gees en rigting van die Skrif." Die navorsing sal God se Woord dus bestudeer om sodoende te bepaal of stamselnavorsing Skrifmatig is of nie.

\section{Stamselnavorsing en terapie met volwasse stamselle}

Die gebruik van volwasse stamselle in navorsing word oor die algemeen as minder problematies beskou (Peters, 2007:25), omdat dit nie nodig is om menslike embrio's te vernietig nie. Die gevoel by baie mense is dat navorsing eerder hierdie materiaal moet gebruik. Tog is daar ook etici en aktiviste wat stamselnavorsing met volwasse stamselle problematies vind (Monitoring stem cell research, 2004:93; Scott, 2006:126-140).

Volgens sommige etici skep stamselnavorsing en moontlike terapie valse hoop by baie siek mense en hulle families. Daar word aangevoer dat siek mense onder 'n valse indruk van 'n geslaagde en gerealiseerde terapie gebring word, terwyl dit nog nie eers seker is of stamselterapie definitief sal slaag nie (Scott, 2006:140-141). Nog erger, sommige aktiviste beskou dit as wreed en immoreel om die hoop van soveel siek mense en hulle families uit te buit, veral in die lig van die feit dat sommige wetenskaplikes beweer dat die moontlikhede van stamselnavorsing totaal oorskat word en dat dit in elk geval waarskynlik net vir 'n sekere inkomstegroep beskikbaar sal wees. Hierteenoor word aangevoer dat mediese navorsing, en veral 'n nuwe ondersoek soos by stamselnavorsing, altyd gedoen word in 
die wete van die gevaar van mislukking en gevolglike onvervulde hoop. Daar is nie 'n ander pad as om oor die potensialiteit van navorsing te debatteer nie (Monitoring stem cell research, 2004:94-95).

Sommige mense voer ook aan dat daar buite verhouding aandag en geld aan stamselnavorsing en moontlike terapie gegee word. Dit moet in gedagte gehou word dat baie mense geen basiese mediese sorg óf enige toegang tot bestaande mediese tegnologie, het nie. Sou dit nie eties meer verantwoord wees om beskikbare geld te gebruik om basiese medisyne meer toeganklik te maak en mense eerder te leer om siekte en gestremdheid te voorkom nie? (Scott, 2006:139.) Die bekommernis bestaan dat die oormatige klem op stamselnavorsing die beginsel van geregtigheid aan almal kan verdring. Moet so baie geld aan navorsing bestee word, terwyl niemand nog seker is of hierdie tegnologie werklik ten volle sal slaag nie? (Peters, 2007:68.) Hierteenoor word aangevoer dat te veel aandag net aan bestaande mediese sorg nuwe mediese navorsing en mediese vooruitgang erg kan benadeel. Dit moet in gedagte gehou word dat die huidige basiese medisyne ook eers eksperimentele navorsing was. 'n Goeie balans is nodig. Dit moet verder in gedagte gehou word dat ontwikkelende lande 'n groot las het met rugmurgdefekte, malaria en tuberkulose. Stamselnavorsing kan werklik bydra tot die ontwikkeling van medisyne en terapie vir hierdie siektes (Monitoring stem cell research, 2004:95; Scott, 2006:143; Peters, 2007:70).

'n Ander groep etici is weer van mening dat wanneer navorsers en medici die pad met stamselnavorsing (en terapie) begin stap, die tegnologie noodwendig sal gly (slippery slope) tot genetiese verbetering en 'n gevolglike verontmenslike posthumane samelewing (Monitoring stem cell research, 2004:86, 94; Peters, 2007:26, 49). Stamselnavorsing gee ' $n$ voet in die deur om aan te hou stap na die mens se ou ideaal tot volmaaktheid om uiteindelik soos God te wees (Gen. 3:5). Laasgenoemde sal stadig, kumulatief en sonder teenstand gebeur. Menslike hubris sal die deur oophou. Die oortuiging bestaan dat embrio's willekeurig geneties gemanipuleer sal word, babas sal in laboratoriumvate groei met die doel om mediese produkte en menslike onderdele te produseer. Hierdeur word die mens se menslikheid (natuur) aangetas, ingemeng in die natuur en God gespeel. Teen die agtergrond van die onmenslike posthumane samelewing wat uiteindelik bewerk sal word, is die moontlike mediese voordeel nie so groot nie (Scott, 2006:136-140). Volgens Kass, soos aangehaal deur Peters (2007:54), reageer baie mense met 'n gevoel van diep instinktiewe weersin (visceral repugnance) teenoor moder- 
ne genetiese tegnologie. Kass meen dat hierdie diep instinktiewe intuïtiewe gevoel dien as 'n morele alarm teen onnatuurlike en gevaarlike genetiese tegnologie. Hierteenoor word die vraag gevra of alle genetiese verbetering noodwendig sleg is. Veronderstel ' $n$ mens kan 'n embrio geneties manipuleer om effektief weerstand teen 'n dodelike virus te bied, waarom sal dit nie gedoen word nie? 'n Gesonde debat kan 'n antwoord gee oor sake wat eties 'n aanvaarbare verbetering is en wat nie. Dit is onnodig om oor 'n klein hoeveelheid mense bekommerd te wees wat die tegnologie moontlik kan misbruik (Van Niekerk, 2005:206-207). En wat die moontlikheid van 'n posthumane samelewing betref, lyk dit onwaarskynlik dat dit sal gebeur. "The steady march of humankind's medical discoveries has been overwhelmingly used for good, not for evil." (Scott, 2006: 144, 187; Peters, 2007:56-57.) Peters (2007:53) waarsku dat hierdie standpunt die natuur vergoddelik en poneer: "We have replaced an avoidance of acting contra deum, against God's will, with a new proscription, against acting contra naturam, against nature. To avoid playing God means for us to avoid acting contrary to nature". Hy sien hierdie etiese beoordeling as niks anders nie as neonaturalisme.

Nog 'n argument wat gewoonlik teen stamselnavorsing aangebied word, is die skenking van eierselle. "Egg donation is an overlooked facet of stem cell research", skryf Scott (2006:146). Sommige stamselnavorsers skep hulle eie embrio's vir navorsing en die ontwikkeling van terapie en daarvoor moet eierselle geskenk word. Alhoewel oortollige embrio's gebruik kan word vir stamselnavorsing, word "vars" eierselle benodig om die invloed van die sitoplasma op genetiese ekspressie, asook die ontwikkeling van die embrio, te bestudeer. Navorsers wat met terapeutiese kloning eksperimenteer benodig ipso facto eierselle, waartydens ook die histoversoenbaarheid nagevors word. Om geskikte eierselle te verkry, is 'n gekompliseerde handeling met gepaardgaande risiko's. Die ovaria word hormonaal oorgestimuleer om so veel as moontlik eierselle te bekom (Scott, 2006:146). Waar 'n vrou gewoonlik een eiersel per maand vir moontlike bevrugting vorm, word daar nou tot 12 of meer eierselle gevorm. Die risiko's verbonde aan hierdie prosedure is die gevaar wat met chirurgiese ingreep gepaard gaan, asook die verhoogde kans vir ovariakanker. Vroue wat eierselle geskenk en swanger geraak het, kan die hiperovulasiesindroom ontwikkel. Sulke vroue kan begin bloei, pyn ervaar en tot 10 eierselle op een slag kan abnormaal vergroot (Peters, 2007:84-85). Of hierdie argument enigsins sterk genoeg is om stamstelnavorsing mee af te wys, is te betwyfel. Baie vroue beskou die skenking van eierselle vir stamsel- 
navorsing as 'n klein opoffering met groot mediese potensiaal. Hierdie altruïstiese motief word oor die algemeen as aanvaarbaar beskou solank so 'n vrou haar eierselle vrywillig skenk en ten volle ingelig is van die moontlike risiko's. Baie etici voeg by dat so 'n vrou nie vir haar genetiese materiaal vergoed mag word nie, maar slegs vir uitgawes deur haar aangegaan in die skenkingsproses. Etici en politici is van oordeel dat die verkoop van eierselle tot die uitbuiting en misbruik van arm vroue en hulle kinders kan lei (Peters, 2007:8485).

Ten spyte van bogenoemde argumente teen die gevare van stamselnavorsing, kan dit nie anders nie as om in die lig van die Skrif (Ps. 119:105) te oordeel dat hierdie tegnologie ernstig ondersoek en nagevors moet word. In die Bybel word twee motiewe gevind waarom erns met stamselnavorsing gemaak moet word (Peters, 2007:61-74):

Die eerste motief is 'n Christologiese motief. Alhoewel bogenoemde bekommernis bestaan, moet dit vanuit die gereformeerde etiek aangevoer word dat oor die algemeen, wêreldwyd aanvaar word dat die mens 'n roeping het om siekte en dus ook die pyn en lyding van die mens, te verlig. Laasgenoemde sluit mediese eksperimentering en moontlike terapie in. Hierdie uitgangspunt dien as motivering vir biomediese navorsing (Monitoring stem cell research, 2004:58). In die Skrif word inderdaad gevind dat siekte nie net aanvaar word nie, maar aggressief bestry word. Christus het nie net sonde aan die kruis kom bestry nie, maar ook die gevolge van die sonde, naamlik siekte. Reeds in die Ou Testament word gesien dat alle moontlike voorsorgmaatreëls getref is om siekte te voorkom, naamlik sanitasie (Eks. 29:14; Deut. 23:12-14), higiëne (Lev. 11:32, 39-40) en kwarantyn (Num. 5:4; vgl. Marais, 1978:198; Fergusson, 1995:787). Volgens Peters (2007:66-67) het Christus ons geleer oor genesing, maar dit ook vir ons gedemonstreer (vgl. genoemde gelykenis van die barmhartige Samaritaan, Luk. 10:30-37). In dié gelykenis definieer Christus naasteliefde (v. 27) as die innige jammerkry (v. 33) van "halfdooie" mense (v. 30) deur hulle tot beterskap en gesondheid te help (v. 34-35). Hierdie gelykenis dien ook tot motivering en roeping om te genees. Dit moet die etikus opval dat Jesus Christus deur siek mense te genees en dooies op te wek, sy houding gedemonstreer het (Cook, 1995b:436). Dit vorm 'n integrale en wesenlike deel van sy werk op aarde (Hurding, 1995:431; König, 2001;185). So word byvoorbeeld gevind dat Christus die skoonmoeder van Petrus van koors genees (Luk. 4:49), talle gestremde mense (Mark. 2; Joh. 5) en doofheid (Mark. 7:5) genees, en vir Lasarus (Joh. 11:33) uit die 
dood opwek (Hurding, 1995:431). "Jesus was a healer." (Peters, 2007:66; König, 2001:185.) Volgens Douma (1997:49) moet 'n mens deur die feit dat Christus mense gesond maak, die vrymoedigheid en reg verkry om ook werklik pogings aan te wend om siekte te genees en te keer (vgl. ook Atkinson, 1995:89; Schuurman, 1994:128; Nilsson \& Kvist, 1995:91). Genesing deur Christus kan nie anders verstaan word as die beoefening van liefde nie (Matt. 14:14). Om te genees is in werklikheid 'n vorm van naasteliefde (vgl. De Bruyn, 1993:158; Monitoring stem cell research, 2004:58; Peters, 2007:6263).

Verder moet genoem word dat tegnologiese ingryping binne God se raad toegelaat word. Die vraag kan gestel word of 'n mens die besluit of wil van God tersyde stel en dus verwerp indien 'n kind of volwassene siek word en jy medies-tegnologies tussenbeide tree. Inenting is ' $n$ mediese voorbeeld hiervan. Binne die gereformeerde leer oor die raad van God is tegnologiese ingryping nog nooit as die tersydestelling en verwerping (of "God speel") van die besluit of wil of raad van God gesien nie. In hierdie verband sê Duvenage (1963: 37) dat die gebruik van middele ook in God se raad opgeneem is (2 Kon. 20:7): "Verder sê Jesaja: Bring 'n vyekoek; en hulle het dit gaan haal en op die sweer gesit, en hy het gesond geword." Hiskia mag 'n vyekoek gebruik om hom te genees en dit word nie verstaan as die tersydestelling en verwerping van God se wil nie (Jer. 8:22; Op. 22:2-3; vgl. Marais, 1978:198-199). Dieselfde geld ook waar Christus spoeg (volwasse stamselle?) gebruik om mense te genees (Joh. 9:6; vgl. Hurding, 1995:321). Mediese ingryping is dus nie 'n poging is om "God te speel" nie (Feinberg \& Feinberg, 1993:219; Scorgie \& Jones, 1997:671). 'n Mens sou nie anders kan nie as om in die lig van bogenoemde feite te konkludeer dat stamselnavorsing en terapie nie net eties aanvaarbaar is nie, maar in die lig van die geweldige genesingskrag daarvan, 'n Goddelike opdrag is.

Die tweede motief is 'n eskatologiese motief (proleptiese etiek). Volgens hierdie motief word etiek nie net deur die skeppingsorde bepaal nie, maar ook deur die herskeppingorde. Ons kyk nie net na hoe God die mens geskape het nie (Gen. 2-3), maar ook na die eindpunt van die mens (Openbaring). Sedert die koms van Jesus Christus en die koms van die Gees van God, wat 'n begin is van die wederkoms (Joh. 14:1-19; 16:12-16), leef ons in die "laaste dae" (Hand. 2:17; Hand. 1:1-2), het die opstanding reeds begin (Joh. $5: 25$ ), het die laaste oordeel reeds begin (Joh. 3:18, 36; 12:31) en het die ewige lewe in die tyd deurgebreek (Joh. 3:36; 11:25-26; 17:3). Daar is in beginsel (kwalitatief wel) geen verskil tussen die 
lewe nou en lewe na die wederkoms nie. Die onderskeid kan verwoord word deur te verwys na die gerealiseerde ewige lewe (of koninkryk) en die finaal-gerealiseerde ewige lewe (of koninkryk). God se wil vir die "nou op aarde" en die "eendag in die hemel" verskil nie. Die Here leer ons dan immers bid "laat u wil ook op die aarde geskied, net soos in die hemel" (Matt. 6:10). Daarom kan Peters (1996:155; 2007 68-69) sy eskatologiese etiek soos volg definieer: "A prolepsis is a concrete actualization within present reality of what we envision will be the case in the future-transformed reality." In hierdie verband sê Van Wyk (1988:230), die "eskatologie het dus nie net te doen met suiwer toekomstige dinge nie, want die toekoms het begin met die koms van Christus en die Gees. Jesus kan nou aangedui word as die Antisipator van die toekoms van God en Sy ryk; Hy is die prolepsis van die voltooiing." Die gelowige, ook die gelowige navorser moet hom/haar beywer vir die nuwe hemel en nuwe aarde (2 Pet. 3:13; Van Wyk, 2001:482). "The biomedical sciences become a means by which one strives to realize that future vision during the present era." (Peters, 2007:68.) 'n Eskatologiese etiek moet uitreik en gryp na wat moet en kan kom. Wat kan en moet kom? Waarvoor moet die mens hom beywer? Gesondheid of gesondheid deur stamselnavorsing? Dit is God se wil dat daar in sy koninkryk nou (Jesus as voorbeeld) en in die toekoms geen siekte sal wees nie, maar genesing (Op. 22:2). Omdat God se wil vir die hemel, ook sy wil vir die aarde is, is dit ons roeping en taak om gesond te maak. Tereg sê Moltmann (aangehaal in Van Wyk, 1986: 229) dat dit vir die teoloog (en Christelike navorser) nie net daarom gaan om die wêreld, die geskiedenis en die mens te interpreteer nie, maar hy/sy moet dit verander deur die verwagting van 'n goddelike verandering.

Uit bogenoemde beredenering is aangetoon dat die gelowige, in ' $n$ positiewe sin, die opdrag en roeping het om gesond te maak. In 'n negatiewe sin kan dieselfde argument ook aangevoer word ten opsigte van die beskerming van menslike lewe. Dit is God se wil dat ons in die gerealiseerde ewige lewe nie mag doodmaak nie (Eks. 20:13; 1 Tim. 1:8), net soos daar in die finaal-gerealiseerde ewige lewe nie dood sal wees nie (Op. 21:4). Myns insiens het hierdie opmerking definitiewe implikasies vir stamselnavorsing. Aan die een kant mag menslike lewe (sigoot, embrio, fetus) nie doelbewus doodgemaak word nie, terwyl aan die ander kant, genetiese navorsing daartoe mag of moet lei dat die ewige lewe "geskep" mag word. Genetiese navorsing deur middel van stamselnavorsing begin vandag verstaan waarom selle verouder en daarom uiteindelik die dood van die mens veroorsaak (Panno, 2006:vii-viii). Dit sou eties 
aanvaarbaar wees vir navorsers om genetiese prosesse af te skakel wat die organisme se dood veroorsaak. Natuurlik sal laasgenoemde doelwit in die gerealiseerde ewige lewe ook sy probleme hê (vgl. Op. 9:6).

\section{Stamselnavorsing en terapie met menslike embrionale stamselle}

\subsection{Inleidend}

Dit is aangetoon dat die stamselnavorsing in die lig van die Skrif as 'n opdrag gesien kan word (vgl. 2). Stamselnavorsing met volwasse stamselle lewer nie ernstige probleme op nie. Wêreldwyd word die gebruik van volwasse stamselle aanvaarbaar beskou (Peters, 2007:78-79). Kan dieselfde egter van embrionale stamselnavorsing gesê word? Die gebruik van embrionale stamselle raak ons diep, nie net omdat dit op 'n wonderbaarlike manier genesing kan bring nie, maar ook omdat die embrio 'n menslike embrio is. lets wat ons almal op 'n stadium was (Van Niekerk, 2005:208; Tada \& Cameron, 2006: $160)$. Dit is die sentrale etiese vraag of die menslike embrio vir die skepping van stamsellyne vernietig mag word (The Ramsey colloquium, 1998:937; Van Niekerk, 2005:202; Scott, 2006:124-126, 138). Is die vernietiging van menslike embrio's om stamselle te oes "hoë tegnologiese kannibalisme"? (Panno, 2006:74.)

\subsection{Argumente ten gunste van die gebruik van embrionale stamselle}

Die algemene vraag wat vandag in die etiese debat met betrekking tot die gebruik van embrionale stamselle gevra word, is wat die sterkste weeg: die vooruitgang van mediese navorsing en die realisering van terapie, of respek vir die menslike embrio. Mag die menslike embrio vernietig en daarmee geëksperimenteer word?

Vir baie etici, weeg die moontlike genesing van menslike siektes (en dus pyn en lyding) baie sterker as die waarde van die menslike embrio (Van Niekerk, 2005:205-208; Scott, 2006:131;143). Peters (2007:118) haal Ronald Green, 'n pro bono etiese adviseur vir 'n groot stamselmaatskappy (Advanced Cell Technology) in Amerika aan: "In my view, the moral claims of the very early embryo do not outweigh those of children and adults that can be helped by hES cell and therapeutic cloning technologies." Die medies-etiese beginsel van beneficence, of goeddoen aan jou naaste, tree hier sterk op die voorgrond. Jy mag vernietig om te genees. Die Bybel leer tog immers dat dit liefde is om (jou) lewe vir jou naaste te gee (1 Joh. 
3:16). Die meeste mense wat hierdie standpunt huldig, meen dat menslike lewe eers twee weke na konsepsie begin (Winston, 2005: 432). Dit moet verder in gedagte gehou word dat sodanige terapie nie net die pasiënt help nie, maar ook groot verligting vir die familie sal wees (Monitoring stem cell research, 2004:55-59). Sommige etici meen dat diegene wat teen eksperimentering argumenteer asook die gebruik van menslike embrio's wat tot genesing in die toekoms kan lei, verantwoordelik gehou moet word vir die huidige en toekomstige lyding en dood van pasiënte (Peters, 2007:73). Hierteenoor word aangevoer dat hierdie standpunt die plig om te genees sien as 'n absolute en allesoorheersende bevel (Monitoring stem cell research, 2004:60). Die reg tot genesing word as belangriker gesien as die reg tot lewe. 'n Mens mag nie die lewe van een mens vernietig met die doel om 'n lewe van iemand anders te red nie (Monitoring stem cell research, 2004:31). Teenstanders teen die gebruik van die menslike embrio is dit eens dat wetenskaplike mediese navorsing geweldig belangrik is, alhoewel nie in 'n allesoorheersende of absolute sin nie (Monitoring stem cell research, 2004:60). Die gevaar om genesing en die verligting van lyding as die hoogste en absolute morele beginsel te sien, hou in dat so ' $n$ persoon geen probleem sal ondervind met die gebruik van belangrike hulpbronne vir minder belangrike sake soos ontspanning, kosmetiek en sosiale seremonies nie. Hiermee saam kan die vraag gevra word of dit regtig van 'n mens verwag kan word om teen jou beginsels (lewe begin by konsepsie) op te tree met die doel om lyding te vermy. Kan 'n mens in so 'n geval verantwoordelik gehou word vir iemand se lyding en dood? (Monitoring stem cell research, 2004:59).

Naas die argument van die verligting van lyding, word vryheid van navorsing, as tweede argument aangebied om met menslike embrionale stamselle te eksperimenteer. Volgens sommige etici word die eksperimentering met die menslike embrio gesien as deel van die mens se basiese reg tot navorsing. Die basiese reg tot navorsing word beskou as deel van die mens se reg op uitdrukking, wat op sy beurt voortvloei uit die reg van spraak en denke. Volgens sommige etici moet die vryheid van navorsing as 'n baie gewigtiger argument ten gunste van embrionale stamselnavorsing as die waarde van die menslike embrio beskou word. Hierteenoor word genoem dat hierdie waarheid nog nooit in 'n hof getoets is nie. Hiermee saam word ook aangevoer dat huidige kontroversiële stamselnavorsing die eksperimentele manipulasie van lewende materie (die mens vir sommige) inhou, wat nie op dieselfde vlak as die teoretiese ondersoek en waarneming van natuurlike objekte beskou kan word nie. Vir sommige kan die vernietiging van menslike embrio's nie beskou word as 
'n reg tot uitdrukking nie (Monitoring stem cell research, 2004:61$62)$.

In die derde plek voer sommige etici aan dat dit tog baie beter is om oortollige menslike embrio's wat tydens die in vitro-bevrugtingsproses tot stand gebring is, vir stamselnavorsing en moontlike terapie te gebruik (Scott, 2006:7; Peters, 2007:80). Tans bestaan die praktyk dat so veel as moontlik embrio's tot stand gebring word met die doel dat, indien die eerste rondte inplasing van embrio's nie tot swangerskap lei nie, daar nog embrio's beskikbaar is om in die baarmoeder te plaas. Tot twintig embrio's op 'n slag word geskep, terwyl baie keer net twee of drie gebruik word (Tada \& Cameron, 2006:89). Baie embrio's word uiteindelik nie deur infertiele egpare gebruik nie (Yu \& Thomson, 2006:3) en word dan vir navorsing geskenk (Scott, 2006:2, 29-30). Studies toon dat daar in Amerika tans ongeveer 400 000-500 000 embrio's geberg word, waarvan ongeveer 3\% uiteindelik vernietig sal word (Monitoring stem cell research, 2004:84; Yu \& Thomson, 2006:3; Peters, 2007:36). Die gebruik van sulke embrio's moet as 'n liefdesdaad beskou word wat tot die genesing van baie mense in die toekoms kan lei. Hierteenoor voer sommige etici aan dat alhoewel die tegnologie van in vitrobevrugting binne die gereformeerde etiek nie as verkeerd beskou hoef te word nie, die skep van oortollige embrio's wel ernstig bevraagteken kan word (Tada \& Cameron, 2006:89). Wanneer die ouers al die embrio's wat verwek is so gou as moontlik vir swangerskap terugplaas, kan in vitro-bevrugting nie per se as onbybels afgemaak word nie (Rheeder, 1999:431). 'n Egpaar mag net soveel embrio's skep, as wat hulle bereid is om veilig vir swangerskap te gebruik (Tada \& Cameron, 2006:203-204). Wanneer oortollige embrio's vir eksperimentering en moontlike terapie gebruik sou word, sou dit beteken dat die skep van oortollige embrio's as aanvaarbaar beskou kan word en dit selfs kan bevorder. Hiermee saam moet in gedagte gehou word dat embrio's van mense 'n inherente waarde en reg tot lewe besit. Dit beteken dat hulle net soos terminale siek persone en mense wat die doodsvonnis ontvang het, nie (vroeër) doodgemaak kan word vir eksperimentering nie. Sodanige inherente waarde en reg tot lewe maak die willekeurige gebruik van embrio's vir eksperimentering onaanvaarbaar. Die besluit om oortollige menslike embrio's te skep en vir eksperimentering te gebruik, bly 'n menslike keuse waartoe hy nie die reg het nie (Monitoring stem cell research, 2004:84-88).

Ander skrywers regverdig die gebruik en die vernietiging van die menslike embrio's, vierdens, deur na die feit te verwys dat baie em- 
brio's in die normale verloop van menslike voortplanting (en seksuele gemeenskap) op 'n natuurlike wyse verlore gaan en sodanig vernietig word. Ongeveer 50\%-60\% sigote sterf binne die eerste dag na bevrugting (Winston, 2005:432; Scott, 2006:25,135; Panno, 2006:77). Volgens sommige wetenskaplikes is die totale embrionale verlies voor swangerskap so hoog as 80\% (Peters, 2007:40). Die argument lui dat indien 'n mens nie embrio's mag vernietig nie, dit ook beteken dat jy nie aan gereelde seksuele gemeenskap mag deelneem nie, omdat laasgenoemde daad direk tot die vernietiging van embrio's lei. Die meeste mense beskou hierdie embrioverlies nie as tragies nie en ons wend ook nie groot pogings aan om dit af te weer of te verminder nie. Die feit dat soveel embrio's op 'n natuurlike wyse verlore gaan en niemand dit as 'n slagting beskou of daaroor treur nie, dui op die feit dat die meeste mense embrio's in hulle vroeë stadium nie eties as gelykstaande met kinders en volwassenes beskou nie. Daarom kan dit anders behandel word (Panno, 2006:78). Hierteenoor word geredeneer dat die natuurlike dood van menslike embrio's en die doelbewuste vernietiging van menslike embrio's ex vivo vir navorsingsdoeleindes nie as moreel gelykstaande beskou kan word nie. Baie dinge gebeur natuurlik, maar dit beteken nie dat ons dit doelbewus mag doen nie. Inderdaad is die natuurlike verlies van lewend-gebore mense $100 \%$, maar dit regverdig nie dat hulle vermoor mag word nie. Daar word ook bygevoeg dat die waarde van die embrio nie deur die mens se emosionele reaksie op die dood daarvan bepaal word nie. Hiermee saam moet die volgende twee sake ook in berekening gebring word: eerstens is dit nie seker hoeveel van hierdie "natuurlike embrioverlies" moontlike mislukkings in die bevrugtingsproses is nie, wat beteken dat daar nooit 'n verenigde en geïntegreerde organisme bestaan het nie. Tweedens is dit ook onduidelik hoeveel van hierdie "natuurlike" verlies deur kontingente en veranderlike omstandighede veroorsaak is soos omgewingsbesoedeling, gifstowwe en endometriese probleme. Dit beteken dat die voorkoming van natuurlike verlies nie so maklik vermybaar is nie (Monitoring stem cell research, 2004:88-89).

\subsection{Argumente teen die gebruik van menslike embrionale stamselle}

\subsubsection{Filosofiese argument}

Vir baie mense begin lewe êrens tussen konsepsie en geboorte. Menslike lewe begin by die volgende punte: die ontwikkeling van die neuralbuis (twee weke), breinaktiwiteit (sewe weke), kapasiteit om 
pyn te voel (twaalf weke), lewensvatbaarheid (26-28 weke), geboorte (39-40 weke) en werklike onafhanklike bestaan (Rheeder, 1999: 334-345).

I believe it is impossible to harm a blastocyst (embrio - ALR). These 100 cells are not conscious of existence and do not feel. The scant beginnings of a nervous system are a week away. During the first month of development, there is no behavioral evidence of neural function, and reflex activity isn't detected until six weeks after fertilization. The first neural circuitry, where a sensory impulse can be forwarded to the brain through the spinal cord, is 11 weeks distant. (Scott, 2006:186; vgl. ook Winston, 2005:432.)

"' $n$ Embrio is in wese slegs 'n versameling selle in 'n uiters vroeë stadium van seldeling en ontwikkeling." (Van Niekerk, 2005:209; Dwakins, 2006:294; Panno, 2006:78.)

Kan hierdie prima facie en empiriese observasie die toets van die logika deurstaan? (Peters, 2007:45.) Teenoor hierdie empiriese argument meen verskeie navorsers dat konsepsie as die begin van menslike lewe beskou moet word (Cooper \& Glazer, 1998:27; Scott, $2006: 130)$. Biologiese ontwikkeling vanaf bevrugting tot geboorte is volgens resente kennis 'n aaneen-, aanmekaar- of kontinue (ononderbroke) proses waarin daar nie kwalitatiewe spronge geïdentifiseer kan word nie (Østnor \& Thunberg, 1995:51; Scott, 2006:127; Peters, 2007:47). Die embrio is 'n integrale geheel (The Ramsey colloquium, 1998:938-939). Volgens Douma (1997:176) bestaan daar vanaf konsepsie 'n mens-in-ontwikkeling. Omdat dit egter nie 'n volgroeide mens is nie, begin 'n nuwe menslike lewensgeskiedenis by konsepsie, wat in 'n kontinue ontwikkelingsproses tot ' $n$ duidelik afgetekende individueel-persoonlike bestaan uitgroei. Die eerste biologiese teken van individualiteit is aanwesig in die feit dat ' $n$ eie program en eie tempo van ontwikkeling, anders as dié van die moeder, gevolg word. Die embrio kan lewe as die moeder reeds dood is en kan sterwe as die moeder nog lewe (Heyns, 1985:7-8; Scott, 2006:130). Om 'n mens te wees, beteken dat jou biologiese eienskappe altyd verander: groei en verouder. Biologiese fases hou nie in dat daar bepaalde kwalitatiewe spronge is waar die mens na ' $n$ biologiese verandering meer waarde verkry het nie (Østnor \& Thunberg, 1995:55-56). Om te ontken dat die fetus vanaf konsepsie ten volle mens is, moet 'n ontologiese substansiële modifikasie, 'n synsverandering, tussen konsepsie en geboorte aangetoon word (Du Toit, 1989:109). "If it is objected that, at five days or fifteen days, the embryo does not look like (of tree op soos - ALR) a human being, it 
must be pointed out that this is precisely what a human being looks like - and what each of you looked - at five or fifteen days of development", skryf The Ramsey colloquium (1998:937; Tada \& Cameron, 2006:205). Twee sake staan dus vas: daar is sprake van 'n mens-in-ontwikkeling en nie van 'n ontwikkeling-na-'n-mens nie; daar is nie onmiddellik 'n ontwikkelde mens nie, so asof daar in die embrionale ontwikkeling verder niks meer gebeur nie. In die lig van en in ooreenstemming met hierdie twee beginsels, kan die volgende onderskeiding gemaak word, naamlik tussen menslik molekulêre lewe en menslik somatiese lewe.

Die wesenlike probleem onderliggend aan die hele poging om die begin van beskermingswaardige lewe (persoon) logies êrens na konsepsie te plaas, word gevind in die feit dat persoonwees (menswees) met funksie verbind word. Die afwesigheid van bepaalde funksies diskwalifiseer die embrio/fetus as 'n beskermingswaardige persoon. Die embrio of fetus moet eers iets kan doen of toon voordat hy/sy as mens kwalifiseer (Rae, 1996:101). Hierteenoor voer Rae (1996:101) aan dat die verhouding tussen wese en funksie baie goed begryp moet word. Funksie vind sy fondament in wese. Die afwesigheid van funksie is nie (noodwendig) 'n verwysing na (kommentaar op) die wese van iets nie. Om te doen is nie sinoniem met om te wees nie. 'n Ding is wat hy is en nie wat hy doen nie.

\subsubsection{Bybelse argumente}

Die gedagte dat (beskermingingswaardige) voorgeboortelike lewe eers veel later na konsepsie begin, is in die eerste plek vreemd aan die Skrif. Volgens Østnor en Thunberg (1995:54) is die gedagte dat lewe "later" (ná konsepsie) begin, gewortel in die Griekse filosofiese tradisie (vgl. ook Panno, 2006:75). Volgens Aristoteles ontvang 'n seun sy siel na die 40e dag en meisies na die 90e dag (Silver, 1998:54). Laasgenoemde gedagte is ook die amptelike Joodse en Moslemstandpunt (Peters, 2007:40) en dit was ook die standpunt van die vroeë kerk soos weerspieël in die Didaché (Van Niekerk, 2005:203). Douma (1997:184) beweer: “Wanneer de vrucht op z'n vroegst na veertig dagen bezield is en pas daarna mens kan heten, dan moet hij vóór dat tijdstip toch minder beschermwaardig zijn!"

Job 3:3 lui soos volg: "Die dag waarop ek gebore is, moes nooit aangebreek het nie, die nag toe gesê is 'n seuntjie het in die wêreld gekom." Die oorspronklike woord vir "in die wêreld gekom" (הרדה) kan vertaal word met konsepsie (bevrugting) of swanger wees of maak (Koehler \& Baumgartner, 1958:242). Die woord הרדה dui op die begin van swangerskap en nie op die dra of geboorteproses self nie 
(Kroeze, 1961:65; Alden, 1993:73). Daarvoor word ander woorde in die Ou Testament gebruik (Stigers, 1980:223). ${ }^{1}$ Die belangrike vraag ontstaan nou na watter tydstip voor geboorte Job hier presies verwys? Vir 'n antwoord op die vraag sal Skrif met Skrif vergelyk moet word (Van Wyk, 1998:6). In die res van die Skrif is daar 'n noue verbinding tussen geslagsgemeenskap en "in die wêreld gekom" (הרחה). Eintlik word dit as een gebeurtenis gesien. Met geslagsgemeenskap is daar sprake van הרדז ("in die wêreld gekom"; Kroeze, 1961:65-66). Geslagsgemeenskap en "in die wêreld gekom" val met mekaar saam (Gen. 4:1, 17; 16:4; 38:18; 2 Sam. 11:4-5; 1 Kron. 7:23; 2 Sam. 12:24). Ons weet vandag dat geslagsgemeenskap en "in die wêreld gekom" (bevrugting) nie met mekaar saamval nie. Die sperms van 'n man resideer ongeveer sewe tot tien uur na geslagsgemeenskap in die voortplantingstelsel van die vrou voor die eiersel vir moontlike bevrugting bereik word (Peters, 1996:112-113). Wat die Skrif wil doen, is om vir die Bybelleser 'n vaste punt te gee om mee te werk en dit is dat geslagsgemeenskap die begin van swangerskap is. Nou ontstaan die vraag: hoe beskou Job die status van "dit" wat met geslagsgemeenskap daargestel is? In aansluiting by bogenoemde gedagte word gevind dat in die tweede versreël verwys word na 'n "seuntjie" (גבֶר) wat die nag met geslagsgemeenskap "die wêreld ingekom het". Dit was nie 'n ding of 'n iets wat die nag verwek is nie, maar 'n "seuntjie". Met geslagsgemeenskap het 'n "seuntjie" die wêreld ingekom. Die Hebreeuse woord vir seuntjie word ook in ander gedeeltes van die Bybel gebruik om na 'n man of eggenoot te verwys (Job 3:23; 16:21) of om 'n volwasse mens aan te dui (Job 10:5; 14:10, 14; Kroeze, 1961:65-66). Dus 'n persoon, soos 'n manlike persoon, is in die nag verwek. Vir hierdie Skrifgedeelte is daar nie 'n prinsipiële verskil tussen die mens wat by geslagsgemeenskap verwek word en die volwasse mens nie (Frame, 1988:93-94; Rae, 1996:105). Alden (1993:73) sê die volgende: "As in other places in the book (Job, 10:10-11) and elsewhere in the Bible (Ps. 139:16; Jer. 1:5), Job believed that his personhood went back to his conception, not merely to his birth." Psalm 51:7 lui soos volg: "Ek was al skuldig toe ek gebore is, met sonde belaai toe my moeder swanger geword het." Op watter tydstip het Dawid se moeder swanger geword? Die Hebreeuse woord wat met swanger word (חימתחני:') vertaal word, beteken letterlik "op hitte wees" (bronstig) in seksuele sin (Koehler \& Baumgarter, 1958:378;

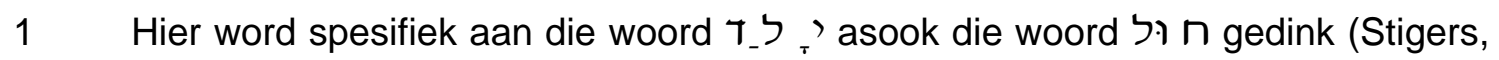
1980:223). 
Ridderbos, 1958:90; Van Groningen, 1988:374). Die gedagte van intense seksuele begeerte gaan geslagsgemeenskap vooraf. Dus wat Dawid sê, is dat hy ("ek") al met sonde bevlek was toe sy moeder 'n seksuele drif tot geslagsgemeenskap gehad het. Hier word die punt van persoonwees en bestaan verby die geslagsdaad self teruggeskuif. Daarom kan Frame (1988:94) die volgende sê: "Ps. 51:7 clearly and strikingly presses this continuity back to the point of conception". Hierdie gedagte in die Ou Testament dat daar van lewe eerder voor konsepsie sprake is as daarna, word ook in die Nuwe Testament bevestig. So word in Hebreërs 7:10 die volgende gesê: “... want Levi was nog in die liggaam van die stamvader toe Melgisedek vir Abraham tegemoet gegaan het". Letterlik staan hier dat Levi nog in die genitalieë van Abraham was (vgl. ook Hand. 2:30; Gen. 25:23; Mal. 1:2; Rom. 9:11; Louw \& Nida, 1989:100). Levi, en nie 'n ding of 'n iets nie, was in die genitalieë van Abraham en daarom kan beweer word dat Levi al handelend in die genitalieë van Abraham kon optree (Heb. 7:9-10; vgl. Marais, 1978:179; Frame, 1988:94).

Scott (2006:186) skryf: "What about human potensial of these cells? I think about this question in terms of potensial persons and actual persons. It is hard for me to imagine how we should treat persons who don't yet exist." Al kan Scott, en ons, voor en by konsepsie nie lewe sien nie, sien God dit, en sien ons dit omdat Hy dit sien, en Hy wil sien dat ons dit sien. God staan met ons voor en na konsepsionele lewe in 'n verbondsverhouding. In Jerermia 1:5 is God self aan die woord: "Voordat Ek jou in die moederskoot gevorm het, het Ek jou geken; voordat jy gebore is, het Ek jou aan My gewy en jou as profeet vir die nasies aangestel." God ken jou al voor jou konsepsie (Luk. 2:21; Ef. 1:4; Frame, 1988:94,106). Die werking van die Heilige Gees in die lewe van Johannes die Doper is al merkbaar voor sy geboorte (Luk. 1:15). Profete soos Jesaja en Jeremia word deur God geroep en geheilig van hulle lewe in die moederskoot af (Jes. 49:1; Barlow, 1995) soos ook bely deur die apostel Paulus (Gal. 1:15). Uit die aard van die saak is Douma (1997:188) korrek wanneer hy beweer dat die gegewens geen uitspraak gee oor die begin van menslike lewe nie. Hierdie gegewens dui wel op die aanwesigheid van God in die beginperiode waartydens die mens nog nie vir die oë van die medemens sigbaar is nie. Wat ook uit baie Skrifgedeeltes opmerklik is, is dat na die voorgeboortelike lewe in persoonlike terme verwys word. In Psalm 139:13 sien Dawid homself in die skoot van sy moeder: "U het my gevorm, my aanmekaargeweef in die skoot van my moeder." Dit is 'n "my", 'n persoonlike 
wese wat in die skoot van die moeder geweef is (Frame, 1988:9394).

Die tweede argument teen die vernietiging van die menslike embrio's word gevind in die feit dat die Skrif die mens as beeld van God oproep om voorgeboortelike lewe eerder te beskerm. Volgens O'Mathúna (1995:203) het die mens as beeld van God verreikende betekenis vir die etiek in die algemeen en die bioetiek in die besonder (vgl. ook Tada \& Cameron, 2006:103). O'Mathúna beweer dat die uitgangspunt en vraag van die Skrif nie is wanneer lewe begin nie, maar eerder hoe 'n mens teenoor voorgeboortelike lewe optree, ongeag wat wetenskaplik as die begin van lewe aangedui mag word. Optrede teenoor voorgeboortelike lewe word nie (alleen) deur die beeldskap van die embrio of fetus bepaal nie, maar word (eerder) bepaal deur die beeldskap van die mens wat met voorgeboortelike lewe werk, soos die in vitro-fertilisasiespesialis en stamselnavorser. In die lig van die Skrif is die vraag na wanneer lewe begin 'n valse probleemstelling. Wat verwag God van die stamselnavorsers as sy beeld? Alle mense is na die beeld van God geskape (Jak. 3:9). Volgens Genesis 1:26-30 beteken beeldskap dat God aan die mens 'n sekere rol toeken: elkeen moet God se verteenwoordiger op aarde wees. Dit beteken dat die mense moet optree soos God wil hê die mens moet optree. Om beeld van God te wees beteken dat die mens die gedagtes, dade en gesindheid van God moet reflekteer. König (2006:62-63) stel dit soos volg: "Ons is die beeld van God as ons in ons hele lewe soos Hy leef, as ons lewe aan Hom herinner, as ons waardesisteem Syne verteenwoordig." Beeldskap is dus nie net 'n gegewe nie, maar ook 'n opdrag: lewe en tree op soos die beeld van God (Ef. 4:24).

Hoe tree God op teenoor voorgeboortelike lewe en hoe moet ons as beeldraers teenoor voorgeboortelike lewe optree? 'n Tema wat baie sterk in die Bybel voorkom, is die feit dat voorgeboortelike lewe beskerm en bewaar moet word (O’Mathúna, 1995:207). Psalm 139:13 lui soos volg: "U het my gevorm, my aanmekaargeweef in die skoot van my moeder." Die Hebreeuse woord wat met aanmekaargeweef (סָָּ) vertaal word, word op ander plekke in die Bybel met beskerming of bedekking vertaal (vgl. Ps. 140:8;2 Davidson, s.a.: 576; Koehler \& Baumgartner, 1958:657; O’Mathúna,1995:207). In vers 15 word 'n soortgelyke gedagte gevind: die Hebreeuse woord (סתר) wat

2 "O Here my God aan wie ek behoort, my kragtige Redder, U beskerm my wanneer die goddeloses my aanval." 
volgens die 1953-vertaling met in die geheim vertaal is, kan ook met "'n plek van veilige bewaring" of "beskerming" vertaal word (vgl. Ps. 32:7;3 119:114;4 Jes. 16:3;5 Davidson, s.a.: 582; O’Mathúna, 1995: 207). Neem verder in ag dat Psalm 139:16 die "entiteit" in die skoot

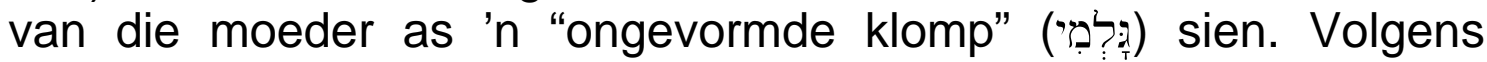

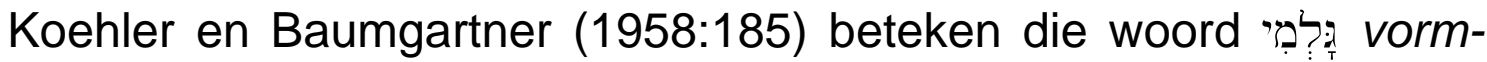
loos. God beskerm jou dus as jy nog vormloos (rond) is en glad nie menslik vertoon nie. " $U$ is my hulp van my geboorte af, reeds voor ek in die wêreld gekom het, het U my beskerm", skryf die digter in Psalm 71:6. Die Hebreeuse woord vir beskerm (סָכמןר) hou die gedagte in van "aan die lewe hou" of van "sorg dat jy voortbestaan" (vgl. Ps. 119:116-117; Davidson, s.a.: 578; Koehler \& Baumgartner, 1958:661). Dit is duidelik dat God die voorgeboortelike lewe wil beskerm en dit inderdaad doen. God is nie net die skenker van lewe nie (Van Niekerk, 2005:207), maar ook die Beskermer van lewe (Hand. 26:17, 22) en verwag dit inderdaad ook van sy kerk en sy beelddraers (Eks. 20:13; 1 Tim. 1:9). Om die embrio te beskerm, kan ook gesien word as die uitvoering van die algemene beginsel in die mediese etiek bekend as nonmaleficence, wat beteken dat 'n mens geen kwaad aangedoen mag word nie (Peters, 2007:35, 47). Volgens Frame $(1988: 12,16)$ is nonmaleficence, ook bekend as die "first, do no harm" (primum non nocere)-beginsel, 'n duidelike Bybelse opdrag (vgl. Eks. 20:13; 21:22; 22:12-36).

Die derde argument wat gebruik word teen die vernietiging van die menslike embrio, is dat die mens as beeld van God juis geroep word om swak en weerlose (voorgeboortelike) menslike lewe te beskerm. Björnsson en Kjems (1995:43) voer aan dat dit 'n deurlopende en sterk tema in die Bybel is dat God voorkeur gee aan die swakkes en die kwesbares en dat hulle beskerm moet word (vgl. ook Christoffersen \& Mortensen, 1995:96). Die weerloses moet juis aan die lewe gehou word (Deut. 14:28-29; 26:12-13) en teen geweld (Job 24:3) en wederregtelike doodmaak beskerm word (Jer. 7:6; 22:3).

$3 \quad$ " $U$ is vir my 'n skuilplek, $U$ beskerm my teen aanvalle, $U$ laat my oorwinningsliedere sing. Sela."

"By U skuil ek, U beskerm my, in u woord stel ek my vertroue."

5

\footnotetext{
"Hulle sê vir Juda: 'Gee vir ons raad, maak 'n plan, laat u skaduwee oor ons val, maak dit donker oor ons op hierdie snikhete dag, beskerm dié wat verjaag is, moenie die vlugtelinge uitlewer nie. Neem Moab se vlugtelinge in beskerming, wees vir ons 'n skuilplek teen dié wat vir ons wil vernietig!'”
} 
God waarsku keer op keer teen kwaadwillige optrede teen die weerloses (Deut. 27:19; Kaiser, 1983:161-163). Volgens Psalm 72:13-14 is swak mense se lewe juis kosbaar (König, 1993:84). Ook Douma (1997:51) is van mening dat daar groot historiese betekenis verbonde is aan die feit dat die Here Jesus juis aan "minderwaardige" lewens soveel aandag skenk, naamlik aan die besetenes, maansiekes, verlamdes, melaatses, blindes en dowes. Atkinson (1995:88) praat van die embrio as voiceless (vgl. ook Higginson, 1995:97; O'Mathúna, 1995:207) en dit vorm inderdaad die swakste en mees weerlose mens denkbaar (Scott, 2006:127; Panno, 2006:76; Peters, 2007:35). 'n Lang tradisie konfronteer die moderne stamselnavorser (asook bewerker van in vitro-bevrugting) met die volgende: wanneer die beginsel van 'n besondere plig teenoor siek mense, kinders, pasgeborenes, ongebore fetusse nog van waarde geag word, waarom word die plig beperk en nie ook van toepassing gemaak op die kwesbaarste van almal nie, naamlik menslike lewe in die eerste week van hulle lewe? (Østnor \& Thunberg, 1995:59.) Volgens The Ramsey colloquium (1998:938) is dit verbasend om te sien hoe die samelewing telkens in dieselfde slaggat van diskriminasie verval, waartydens die vermoënde en invloedryke gedeelte van die samelewing die kragtelose en magtelose gedeelte in die samelewing van morele gelykheid uitsluit. Dit is die kerk se taak om menslike embrionale lewe, al is dit hoe klein, teen diskriminasie te beskerm (Tada \& Cameron, 2006:160). Daarom merk Vorster (2007:221) tereg op dat die kwaliteit van 'n demokrasie juis gekenmerk word deur die wyse waarop die mees kwesbare mense in die samelewing hanteer word.

In die lig van bogenoemde beredenering vind ek die uitspraak van Van Niekerk (2005:205) ietwat onregverdig as hy sê dit is "arrogant en totaal onsimpatiek om noodsaaklike navorsing te probeer stop in naam van 'n beweerde besorgdheid oor die lewe van 'n klompie selle". 'n Mens wonder of hy met die uitspraak nie homself skuldig maak aan 'n té "vinnige morele oordeel" waarteen hy self waarsku nie.

\subsection{Indien volwasse stamselnavorsing nie slaag nie}

Mense wat teen embrionale stamselnavorsing is, voer aan dat volwasse stamselle die gebruik van embrionale stamselle ten volle sal vervang (Rheeder, 2008). Daar is reeds daarop gewys dat dit nog nie 'n uitgemaakte saak is nie en dat dit tans eerder lyk asof embrionale stamselle nie vervangbaar is nie. Peters (2007:38-39) is daarvan oortuig dat terapie nie sonder embrionale stamselle ontwik- 
kel kan word nie en skryf: "This attempt to circumvent the ethical challenge by sidestepping blastocyst disaggregation lacks scientific support" (vgl. ook Panno, 2006:xii). Die feit dat volwasse stamselle in sommige gevalle wel genesing bewerk het, en dat navorsers dit reggekry het om 'n ten volle gedifferensieerde sel te reprogrammeer om soos 'n embrionale stamsel op te tree, is nog 'n onsekere deurbraak. Die hipotetiese vraag wat nou aan die orde kom is die volgende: veronderstel navorsing toon sonder twyfel aan dat nét embrionale stamselle effektief en met groot terapeutiese sukses gebruik kan word, hoe moet die kerk eties daaroor dink? Moet stamselnavorsing heeltemal gestop word? (Peters, 2007:47.) Hier is waarskynlik sprake van 'n botsing van pligte waar 'n hartseer keuse gemaak moet word as gevolg van die gebrokenheid van die menslike lewe (De Bruyn, 1993:13). Volgens Douma (1981:121) is nie elke gebod van God 'n absolute gebod nie - slegs die eerste en die derde gebod is absolute gebooie. Miskien is Van Niekerk (2005:210) reg as hy beweer dat lewe geen absolute waarde het nie en dat daar soms in die lewe situasies opduik waarin ons tussen menslike lewe en 'n ander waarde moet kies, en dat laasgenoemde dan die voorkeur moet kry.

\section{Slot}

Stamselnavorsing en terapie moet in die lig van die Skrif positief beoordeel word en moet met Christus as voorbeeld selfs as ' $n$ opdrag gesien word. Stamselterapie wat deur stamselle uit die liggaam bewerk word, lewer geen etiese probleme op nie, alhoewel sommige etici wel van mening is dat stamselnavorsing en terapie in die algemeen nie aanvaarbaar is nie. Alhoewel sommige navorsers meen dat die menslike embrio met die oog op genesing vernietig mag word (Dawkins, 2006:291-298), kan hierdie handeling nie die toets van die Skrif deurstaan nie. Die gedagte dat beskermingswaardige lewe enige tyd na konsepsie begin, is vreemd aan die Skrif. Die Bybel roep die mens as beeld van God op om, soos God, alle voorgeboortelike en weerlose menslike lewe te beskerm. Om met menslike embrio's te eksperimenteer, of om hulle te skep met die doel om te vernietig, is eties onaanvaarbaar. 


\section{Geraadpleegde bronne}

ALDEN, R.L. 1993. Job. Nashville: Broadman. (The new American commentary: an exegetical and theological exposition of Holy Scripture NIV text. Vol. 11.)

ATKINSON, D.J. 1995. Life, health and death. (In Atkinson, D.J. \& Field, D.H., eds. New dictionary of Christian ethics and pastoral theology. Downers Grove: InterVarsity. p. 87-92.)

BARLOW, J.H. 1995. A Biblical perspective on abortion: center for reformed theology and apologetics. http://www.reformed.org/social/abortion.html Date of access: 4 Jan. 1999.

BJÖRNSSON, B. \& KJEMS, L. 1995. In vitro fertilization: a letter to a childless couple. (In Mortensen, V., ed. Life and death: moral implications of biotechnology. Geneva: WCC Publications. p. 41-49.)

CHRISTOFFERSEN, S.A. \& MORTENSEN, V. 1995. Ethics and counseling: a letter to a fellow pastor. (In Mortensen, V., ed. Life and death: moral implications of biotechnology. Geneva: WCC Publications. p. 94-97.)

COOK, E.D. 1995b. Health and health care. (In Atkinson, D.J. \& Field, D.H., eds. New dictionary of Christian ethics and pastoral theology. Downers Grove: InterVarsity. p. 435-437.)

COOPER, S.L. \& GLAZER, E.S. 1998. Choosing assisted reproduction: social, emotional \& ethical considerations. Indianapolis: Perspectives.

DAVIDSON, B. s.a. Analytical Hebrew and Chaldee Lexicon. Florida: Mcdonald.

DE BRUYN, P.J. 1993. Die tien gebooie. Midrand: Varia.

DOUMA, J. 1981. Verantwoord handelen: ethisch kommentaar. Amsterdam: Ton Bolland.

DOUMA, J. 1997. Medische ethiek. Kampen: Uitgeverij Van den Berg.

DU TOIT, D. 1989. Antropologie en embriologie. (In Theron, P.F. \& Kinghorn, J., reds. Koninkryk, kerk en kosmos: 'n huldigingsbundel ter ere van prof. W.D. Jonker. Bloemfontein: Pro Christo Publikasies. p. 101-111.)

DUVENAGE, B. 1963. Hoofpunte van die gereformeerde geloofsleer. Potchefstroom: Pro Rege-Pers.

DWAKINS, R. 2006. The God delusion. London: Transworld.

FEINBERG, J.S. \& FEINBERG, P.D. 1993. Ethics for a brave new world. Wheaton: Crosswaybooks.

FERGUSSON, D.A.N. 1995. Sick, care of. (In Atkinson, D.J. \& Field, D.H., eds. New dictionary of Christian ethics and pastoral theology. Downers Grove: InterVarsity. p. 787-788.)

FRAME, J.M. 1988. Medical ethics: principles, persons and problems. Phillipsburg: Presbyterian \& Reformed Publishing.

HEYNS, J.A. 1985. Mediese etiek. Pretoria: NG Kerkboekhandel.

HIGGINSON, R.A. 1995. Ethics of medical care. (In Atkinson, D.J. \& Field, D.H., eds. New dictionary of Christian ethics and pastoral theology. Downers Grove: InterVarsity. p. 93-99.)

HURDING, R.H. 1995. Healing. (In Atkinson, D.J. \& Field, D.H., eds. New dictionary of Christian ethics and pastoral theology. Downers Grove: InterVarsity. p. 431-434.)

KAISER, W.C. 1983. Toward an Old Testament ethics. Michigan: Zondervan.

KOEHLER, L. \& BAUMGARTNER, W. 1958. Lexicon in veteris testamenti libros. Leiden: Brill. 
KÖNIG, A. 1993. Menseregte: menslike mense: gelowig nagedink. DI. 5. Oor die mens en sonde in die praktyk. Halfway House: Orion.

KÖNIG, A. 2001. Fokus op die 300 geloofsvrae wat mense die meeste vra: sleutelbegrippe van die Christelike geloof: 'n verwysingsgids vir elke huis. Wellington: Lux Verbi.BM.

KÖNIG, A. 2006. Die groot geloofswoordeboek: meer as 500 kernwoorde van die Christelike geloof maklik gemaak. Vereniging: Christelike Uitgewersmaatskappy.

KROEZE, J.H. 1961. Job: commentaar op het Oude Testament. Kampen: Kok.

LOUW, J.P. \& NIDA, E.A. 1989. Greek-English lexicon of the New Testament based on semantic domains. Cape Town: National Book.

MARAIS, P.W. 1978. Die tien woorde van God. Pretoria: NG Kerkboekhandel.

MONITORING STEM CELL RESEARCH. 2004. A report of the president's council on bioethics. http://www.bioethics.gov/reports/stemcell/ index.html Date of access: 23 May 2007.

MORTENSEN, V. 1995. Preface. (In Mortensen, V., ed. Life and death: moral implications of biotechnology. Geneva: WCC Publications. p. i-x.)

NEDERLANDSE GELOOFSBELYDENIS. 2001. (In Die Psalmboek. Wellington: NG Kerkuitgewers. p. 5-32.)

NGB

kyk NEDERLANDSE GELOOFSBELYDENIS

NILSSON, G. \& KVIST, H. 1995. Legislation on human and animal research: a letter to a parliamentarian. (In Mortensen, V., ed. Life and death: moral implications of biotechnology. Geneva: WCC Publications. p. 86-93.)

O'MATHÚNA, D.P. 1995. The Bible and abortion: what of the image of God? (In Kilner, J.F., Cameron, N.M de S. \& Schiedermayer, D.L., eds. Bioethics and the future of medicine: a Christian appraisal. Michigan: Eerdmans. p. 199-211.)

ØSTNOR, L. \& THUNBERG, A. 1995. Fertilized eggs and pre-implantation diagnosis: a letter to a medical researcher. (In Mortensen, V., ed. Life and death: moral implications of biotechnology. Geneva: WCC Publications. p. 50-63.)

OUWENEEL, W.J. 1978. Operatie supermens: een Bijbels-biologiese blik op de toekoms. 3e uitg. Groningen: De Vuurbraak.

PANNO, J. 2006. Stem cell research: medical applications \& ethical controversy. New York: Checkmark Books.

PETERS, T. 1996. For the love of children: genetic technology and the future of the family. Louisville: Wesminister John Knox.

PETERS, T. 2007. The stemcell debate. Minneapolis: Fortress.

RAE, S.B. 1996. Brave new families: Biblical ethics and reproductive technologies. Grand Rapids: Baker Books.

RAMSEY COLLOQUIUM. 1998. The inhuman use of human beings: a statement on embryo research by the Ramsey colloquium. (In Lammers, S.E. \& Verhey, A., eds. On moral medicine: theological perspectives in medical ethics. 2nd ed. Grand Rapids: Eerdmans p. 936-941.)

RHEEDER, A.L. 1999. Selektiewe voortplanting by die mens: 'n teologies-etiese studie. Potchefstroom: PU vir CHO. (Th.D.-proefskrif.)

RHEEDER. A.L. 2008. Stamselnavorsing en terapie: 'n oorsig oor die uitvoerbaarheid daarvan met meegaande etiese implikasies. In die Skriflig, 42(3):469-497. 
RIDDERBOS, J. 1958. De psalmen DI. 2: Commentaar op het Oude Testament. Kampen: Kok.

SCHUURMAN, E. 1994. Perspectives on technology and culture. Potchefstroom: PU for CHE. (Series F2: Brochures of the Institute for Reformational Studies. No. 60.)

SCORGIE, G.G. \& JONES, C.F.E. 1997. Human life is not sheep: an ethical perspective on cloning. Journal of the evangelical theological society, 40(4):663-678.

SCOTT, T.S. 2006. Stem cell now: from the experiment that shook the world to the new politics of life. New York: Pi Press.

SILVER, L.M. 1998. Remaking Eden: cloning and beyond in a brave new world. London: Weidenfeld \& Nicolson.

STIGERS, H.G. 1980. הרָזה. (In Harris, R.L., ed. Theological wordbook of the Old Testament. Vol. 1. Chicago: Moody. p. 538.)

TADA, J.E. \& CAMERON, M. DE S. 2006. How to be a Christian in a brave new world. Grand Rapids: Zondervan.

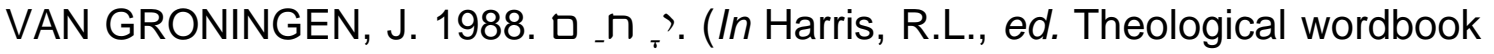
of the Old Testament. Volume 1. Chicago: Moody. p. 374.)

VAN NIEKERK, A.A. 2005. Geloof sonder sekerhede: besinning vir eietydse gelowiges. Wellington: Lux Verbi.BM.

VAN WYK, J.H. 1986. Gesindheid en gestalte. Pretoria: NG Kerkboekhandel.

VAN WYK, J.H. 1988. Spel met sperma? Oor voortplantingstegniek en -etiek. Potchefstroom: PU vir CHO. (Wetenskaplike bydraes. Studiestuk nr. 244:1-15, Maart.)

VAN WYK, J.H. 1991. Moraliteit en verantwoordelikheid: opstelle oor politieke etiek. Potchefstroom: PU vir CHO. (Wetenskaplike bydraes van die PU vir CHO. Reeks A: Geesteswetenskappe, nr. 77.)

VAN WYK, J.H. 1998. Wie lê die Skrif reg uit - en hoe? Die Kerkblad, 101(3048):6-7.

VAN WYK. J.H. 1999. Kloning: konflik tussen wat kan en wat mag: 'n voorlopige ondersoek vanuit teologies-etiese perspektief. In die Skriflig, 33(1):81-97.

VAN WYK, J.H. 2001. Die nuwe hemel en nuwe aarde: dogmatiese en etiese oorwegings oor 'n aspek van die eskatologie. (In Van Wyk, J.H. Etiek en eksistensie in koninkrykperspektief. Potchefstroom: Potchefstroomse Teologiese Publikasies. p. 465-491.)

VORSTER, J.M. 2007. Christian attitude in the South African liberal democracy. Potchefstroom: Potchefstroom Theological Publications.

WINSTON, R. 2005. The story of God: a personal journey into the world of science and religion. London: Bantambooks.

YU, J. \& THOMSON, J.A. 2006. Embryonic stem cells: regenerative medicine department of health and human services. http://stemcells.nih.gov/info/ scireport/2006report Date of access: 23 Oct. 2007.

\section{Kernbegrippe:}

embrio

stamsel

stamselnavorsing

teologies-etiese beoordeling

voorgeboortelike lewe 


\section{Key concepts:}

embryo

prenatal life

stem cell

stem cell research

theological-ethical evaluation 
